\title{
Nutrient ratios driven by vertical stratification regulate phytoplankton community structure in the oligotrophic western Pacific Ocean
}

\author{
Zhuo Chen ${ }^{1,3}$, Jun Sun ${ }^{2,3}$, Ting Gu ${ }^{3}$, Guicheng Zhang ${ }^{3}$, and Yuqiu Wei ${ }^{4}$ \\ ${ }^{1}$ College of Biotechnology, Tianjin University of Science and Technology, Tianjin 300457, China \\ ${ }^{2}$ College of Marine Science and Technology, China University of Geosciences (Wuhan), Wuhan, Hubei 430074, China \\ ${ }^{3}$ Research Centre for Indian Ocean Ecosystem, Tianjin University of Science and Technology, Tianjin 300457, China \\ ${ }^{4}$ Yellow Sea Fisheries Research Institute, Chinese Academy of Fishery Sciences, Qingdao 266071, China
}

Correspondence: Jun Sun (phytoplankton@163.com)

Received: 1 July 2021 - Discussion started: 6 July 2021

Revised: 4 November 2021 - Accepted: 6 November 2021 - Published: 6 December 2021

\begin{abstract}
The stratification of the upper oligotrophic ocean has a direct impact on biogeochemistry by regulating the components of the upper-ocean environment that are critical to biological productivity, such as light availability for photosynthesis and nutrient supply from the deep ocean. We investigated the spatial distribution pattern and diversity of phytoplankton communities in the western Pacific Ocean (WPO) in the autumn of 2016, 2017, and 2018. Our results showed the phytoplankton community structure mainly consisted of cyanobacteria, diatoms, and dinoflagellates, while the abundance of Chrysophyceae was negligible. Phytoplankton abundance was high from the equatorial region to $10^{\circ} \mathrm{N}$ and decreased with increasing latitude in spatial distribution. Phytoplankton also showed a strong variation in the vertical distribution. The potential influences of physicochemical parameters on phytoplankton abundance were analyzed by a structural equation model (SEM) to determine nutrient ratios driven by vertical stratification to regulate phytoplankton community structure in the typical oligotrophic ocean. Regions with strong vertical stratification were more favorable for cyanobacteria, whereas weak vertical stratification was more conducive to diatoms and dinoflagellates. Our study shows that stratification is a major determinant of phytoplankton community structure and highlights that physical processes in the ocean control phytoplankton community structure by driving the balance of chemical elements, providing a database to better predict models of changes in phytoplankton community structure under future ocean scenarios.
\end{abstract}

\section{Introduction}

Phytoplankton contribute nearly half of global primary production (Field et al., 1998) and represent an important part of biogeochemical cycling and transformation (Falkowski et al., 1998). Marine phytoplankton link the cycling of different elements through their demand for multiple nutrients such as nitrogen $(\mathrm{N})$, phosphorus $(\mathrm{P})$, or iron and their relative availability (Hillebrand et al., 2013). The Redfield ratio is probably the most powerful generalization and cornerstone of the marine biogeochemical cycle (Redfield et al., 1963; Schindler, 2003). The nutrient requirements of phytoplankton are limited by the environmental conditions in which they grow, and nutrient limitation increases the $\mathrm{N}: \mathrm{P}$ ratio of primary production (Carlson, 2002; Fogg, 1983; Karl et al., 1998). Nitrogen fixation by phytoplankton may deplete phosphorus from the upper ocean, causing an increase to the $\mathrm{N}: \mathrm{P}$ ratios (Karl et al., 2001). The photosynthesis does not cease, even when there are not enough nutrients to grow (Bertilsson et al., 2003; Geider et al., 1998; Goldman et al., 1979).

Upper-ocean stratification plays an important role in the climate system and in many marine biogeochemical processes. The degree of vertical mixing is controlled by the strength of near-surface density stratification (Cronin et al., 2013; Qiu et al., 2004), which impacts the formation of the surface mixed layer (ML) and the entrainment process at the ML's base. The ML depth directly modulates the oceanic reaction to atmospheric forcing and the ocean ventilation process that includes the sinking of water masses into the ocean 
interior, accompanied by heat, carbon, and oxygen. Upperocean stratification can directly affect important processes such as biogeochemistry and primary production by regulating the light supply for photosynthesis and nutrient supply from the subsurface ocean (Yamaguchi et al., 2019). While the strengthened stratification may produce better light availability for the phytoplankton community, it will also prevent vertical nutrient supply to the euphotic zone from the deep sea (Doney, 2006). Previous studies have shown that net primary production (NPP) shows a stronger linear decrease with stronger vertical stratification and a significant decrease in surface nitrate and phosphate concentrations. The decrease in NPP can be partly explained by the increase in vertical stratification that leads to changes in nutrient concentration (Yamaguchi et al., 2019).

In the present study, we focused on the vertical structure of the change in the ocean temperature and salinity, i.e., the change in the density stratification. The vertical stratification index (VSI) used in this study is the potential density difference between the surface layer and the depth of $200 \mathrm{~m}$ $(\Delta \rho 200)$, which can quantify the strength of the upper-ocean stratification well (Mena et al., 2019). The purpose of this study is to determine the community composition mechanisms that drive phytoplankton in the oligotrophic region. These mechanisms are related to vertical stratification and nutrient ratios. We explored how vertical stratification affects the composition of phytoplankton communities. We hypothesized that vertical stratification might regulate phytoplankton abundance and community composition by driving the ratio of nutrients.

\section{Materials and methods}

\subsection{Study area and sampling}

This study relied on the shared voyage of the western Pacific Ocean (WPO; $0-20^{\circ} \mathrm{N}, 120-130^{\circ} \mathrm{E}$ ), commissioned by the National Natural Science Foundation of China. Physical, biological, chemical, and geological surveys were carried out from September to November in 2016, 2017, and 2018 aboard the R/V Kexue. The sampling stations used in this study are shown in Fig. 1; the sampling layers were 5, $25,50,75,100,150$, and $200 \mathrm{~m}$. Phytoplankton samples from different water layers were placed in $1 \mathrm{~L}$ polyethylene bottles, fixed in formaldehyde solution (3\%), and stored in the dark. Nutrient samples from different layers were placed in PE bottles, frozen, and stored at $-20^{\circ}$ for laboratory nutrient analysis.

\subsection{Identification of phytoplankton}

After returning to the laboratory, the Utermöhl method was applied for phytoplankton analysis. A $1 \mathrm{~L}$ subsample was allowed to stand for $48 \mathrm{~h}$, after which $800 \mathrm{~mL}$ supernatant was removed carefully by siphoning through a catheter, tak- ing care to prevent the catheter from touching the bottom of the bottle. Thereafter, the remaining $200 \mathrm{~mL}$ of liquid was gently mixed and half of it was further concentrated with a $100 \mathrm{~mL}$ sedimentation column (Utermöhl method) for $48 \mathrm{~h}$ sedimentation (Sun et al., 2002). The phytoplankton species were identified and enumerated under an inverted microscope (AE2000, Motic, Xiamen, China) at $400 \times$ (or 200×) magnification. Phytoplankton identification was conducted as described by Jin and Chen (1965), Yamaji (1991), and Sun and Liu (2002), and the World Register of Marine Species (http://www.marinespecies.org, last access: 12 May 2020). Species identification was as close as possible to the species level. The minimum size of the organisms identified and counted is $20 \mu \mathrm{m}$.

\subsection{Laboratory nutrient analysis}

The Technicon AA3 Auto-Analyzer (Bran + Luebbe, Norderstedt, Germany) based on classical colorimetric methods was used for the analysis and determination of nutrients (Grasshoff et al., 2009). Soluble inorganic phosphorus $\left(\mathrm{PO}_{4}-\mathrm{P}\right)$ was determined by the phosphomolybdenum blue method with a limit of detection of $0.02 \mu \mathrm{mol} \mathrm{L}^{-1}$, dissolved silicate $\left(\mathrm{SiO}_{3}-\mathrm{Si}\right)$ was determined by the silicon molybdenum blue method with a limit of detection of $0.02 \mu \mathrm{mol} \mathrm{L}^{-1}$, nitrate $\left(\mathrm{NO}_{3}-\mathrm{N}\right)$ was determined by the cadmium column method with a limit of detection of $0.01 \mu \mathrm{mol} \mathrm{L}^{-1}$, nitrite $\left(\mathrm{NO}_{2}-\mathrm{N}\right)$ was determined by the naphthalene ethylenediamine method with a limit of detection of $0.01 \mu \mathrm{mol} \mathrm{L}-1$ (Dai et al., 2008), and ammonia $\left(\mathrm{NH}_{4}-\mathrm{N}\right)$ was determined by the sodium salicylate method with a limit of detection of $0.03 \mu \mathrm{mol} \mathrm{L}^{-1}$ (Guo et al., 2014; Pai et al., 2001). The nitrogen-to-phosphorous $(\mathrm{N}: \mathrm{P})$ ratio was calculated by dividing nitrogen concentration $\left(\mathrm{NO}_{3}^{-}+\mathrm{NO}_{2}^{-}\right)$by phosphate concentration.

\subsection{Analysis and methods}

A SBE911 conductivity, temperature, and depth (CTD) sensor and standard Sea-Bird Electronics methods were used to process recorded hydrological parameters. The depth of the mixed layer (ML) is calculated as follows:

$$
(S, T)=\left(S_{\text {ref }}, T_{\text {ref }}-\Delta T\right),
$$

where $S$ and $T$ are the salinity and temperature, respectively, and $S_{\text {ref }}$ and $T_{\text {ref }}$ are the temperature and salinity at $5 \mathrm{~m} ; \Delta T$ is equal to $0.5^{\circ} \mathrm{C}$.

We calculated the vertical stratification index (VSI) to indicate the degree of vertical stratification of the water column:

$\mathrm{VSI}=\Sigma\left[\delta_{\theta}(m+1)-\delta_{\theta}(m)\right]$,

where $\delta_{\theta}$ is the potential density anomaly and $m$ is the depth from 5 to $200 \mathrm{~m}$. 


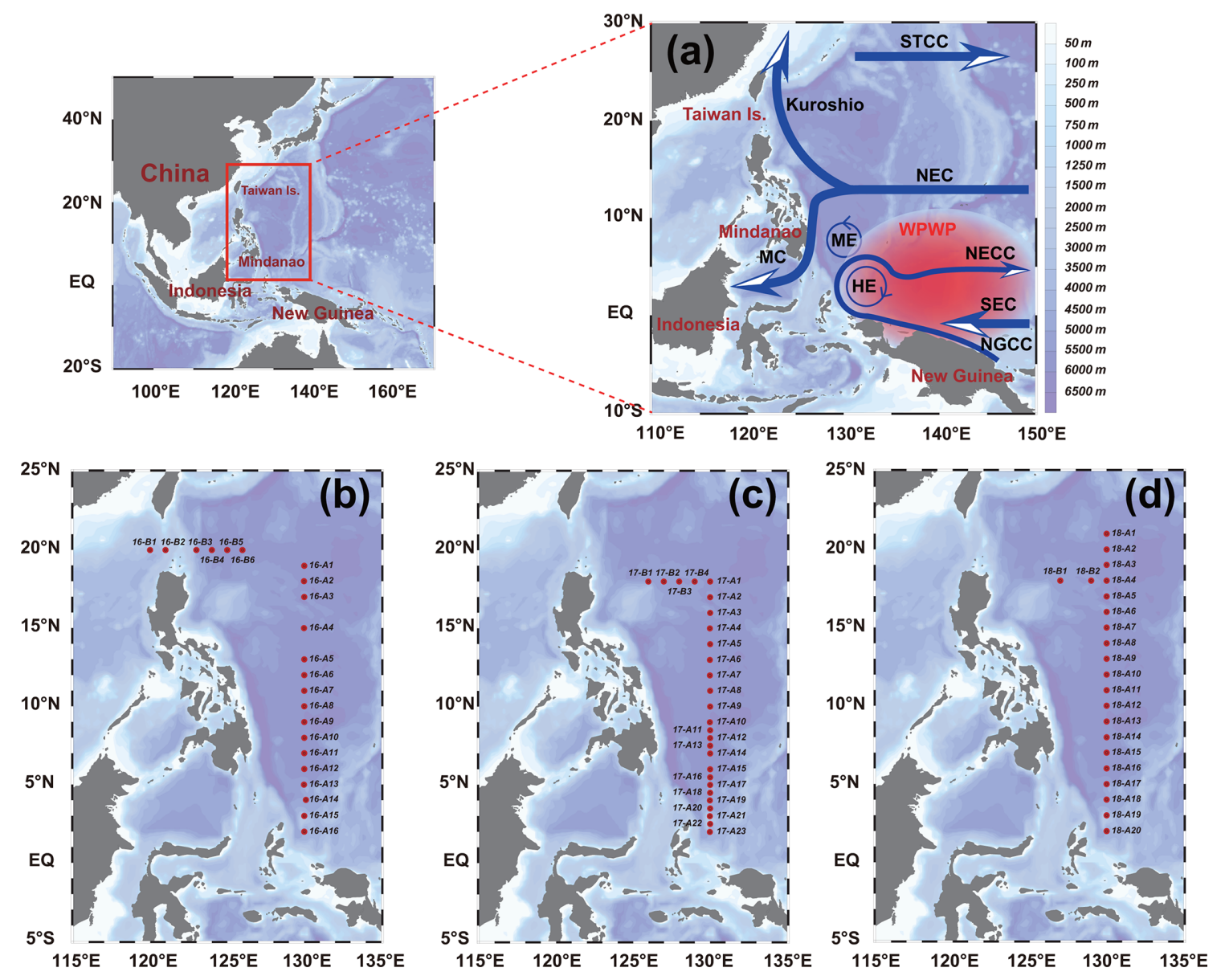

Figure 1. Stations in the western Pacific Ocean (WPO) of three cruises. (a) Current systems of the WPO; (b, c, d) sampling stations of the 2016, 2017, and 2018 cruises, respectively. The station at $130^{\circ} \mathrm{E}$ forms section A, and the station at $20^{\circ} \mathrm{N}$ forms section B. Map of the WPO shows the major geographic names and the surface currents, including the Subtropical Counter Current (STCC), the North Equatorial Current (NEC), the North Equatorial Counter Current (NECC), the South Equatorial Current (SEC), the New Guinea Coastal Current (NGCC), the Mindanao Current (MC), the Mindanao Eddy (ME), and the Halmahera Eddy (HE).

The abundance of phytoplankton cells in the water column was calculated through the trapezoidal integral method (Zhu et al., 2019):

$P=\left\{\sum_{i=1}^{n-1} \frac{P_{i+1}+P_{i}}{2}\left(D_{i+1}-D_{i}\right)\right\} /\left(D_{n}-D_{1}\right)$,

where $P$ is the average value of phytoplankton abundance in water column, $P_{i}$ is the abundance value of phytoplankton in layer $i, i+1$ is the layer $i+1, D_{n}$ is the maximum sampling depth, $D_{i}$ is the depth of layer $i$, and $n$ is the sampling level.

We clustered all species based on Bray-Curtis similarity distance over the 3 years, and the results showed four distinct regions using the primer (version 6). Distance-based redundancy analysis (db-RDA) and principal co-ordinates analysis (PCoA) were performed using the $\mathrm{R}$ package vegan (version 2.5-7) (Oksanen et al., 2020) to explain the relationship between environmental parameters, i.e., temperature, salinity, depth, VSI, dissolved inorganic nitrogen (DIN), dissolved in- organic phosphorus (DIP), and dissolved silicate (DSi), and phytoplankton community structure. The results were visualized using the R package ggplot2 (version 3.3.2). A structural equation model (SEM) was used to assess the relative direct and indirect impact of physical and chemical parameters on phytoplankton abundance. The chi-square test $\left(\chi^{2}\right)$, comparative fit index (CFI), and goodness-of-fit index (GFI) were used to assess the model fit.

\section{Results}

\subsection{Hydrographic features of the study area during the sampling years}

The surface temperature and salinity of the surveyed sea area in 2016, 2017, and 2018 are shown in Fig. 2. In general, the temperature increased with decreasing latitude, and the stations near the Equator exhibited the highest temperature; in 
contrast, the salinity showed an opposite trend to that of temperature, with a high value from 15 to $20^{\circ} \mathrm{N}$. The surface temperature (Fig. 2) of the surveyed area in 2016 ranged from $28.58^{\circ} \mathrm{C}$ (station $16-\mathrm{B} 1$ ) to $30.14^{\circ} \mathrm{C}$ (station 16-A16), with an average of $29.43^{\circ} \mathrm{C}$. The surface salinity (Fig. 2) of the surveyed area in 2016 ranged from 33.80 (station 16-B2) to 34.65 (station 16-A2), with an average of 34.32 . The surface temperature (Fig. 2) of the surveyed area in 2017 ranged from $27.91{ }^{\circ} \mathrm{C}$ (station $17-\mathrm{A} 4$ ) to $30.19^{\circ} \mathrm{C}$ (station $17-\mathrm{A} 20$ ), with an average of $29.26^{\circ} \mathrm{C}$. The surface salinity (Fig. 2) of the surveyed area in 2017 ranged from 33.38 (station 17-A16) to 34.64 (station 17-B4), with an average of 33.94. The surface temperature (Fig. 2) of the surveyed sea area in 2018 ranged from $26.33^{\circ} \mathrm{C}$ (station 18-B1) to $29.79^{\circ} \mathrm{C}$ (station 18-A17), with an average of $28.83^{\circ} \mathrm{C}$. The surface salinity (Fig. 2) of the surveyed sea area in 2018 ranged from 33.77 (station 18A14) to 34.64 (station 18-B1), with an average of 34.21.

The profile distribution of temperature and salinity based on the cross-sectional data of different water layers at each station obtained from the survey is shown in Fig. 2. The temperature of the shallow-water column $(0-100 \mathrm{~m})$ is higher than that of the deep-water column $(100-200 \mathrm{~m})$. The salinity values of the deep-water bodies $(100-200 \mathrm{~m})$ were higher than those of the shallow-water bodies $(0-100 \mathrm{~m})$. The values of temperature and salinity in 2016, 2017, and 2018 did not change significantly. The temperature of the section in 2016 ranged from $12.16^{\circ} \mathrm{C}(200 \mathrm{~m}$ at station $16-\mathrm{A} 11)$ to $30.14^{\circ} \mathrm{C}$ ( $5 \mathrm{~m}$ at station $16-\mathrm{A} 16$ ), with an average of $25.74^{\circ} \mathrm{C}$. The salinity of the section in 2016 ranged from 33.80 ( $5 \mathrm{~m}$ at station 16-B2) to 35.39 (150 m at station 16-A16), with an average of $34.61{ }^{\circ} \mathrm{C}$. The temperature of the section in 2017 ranged from $11.16^{\circ} \mathrm{C}(200 \mathrm{~m}$ at station $17-\mathrm{A} 13)$ to $30.19^{\circ} \mathrm{C}$ ( $5 \mathrm{~m}$ at station $17-\mathrm{A} 20$ ), with an average of $25.18^{\circ} \mathrm{C}$. The salinity of the section in 2017 ranged from 33.38 ( $5 \mathrm{~m}$ at station 17-A16) to 35.24 (150 m at station 17-A23), with an average of 34.46. The temperature of the section in 2018 ranged from $9.65^{\circ} \mathrm{C}(200 \mathrm{~m}$ at station $18-\mathrm{A} 14)$ to $29.79^{\circ} \mathrm{C}$ (5 m at station 18-A17), with an average of $24.22^{\circ} \mathrm{C}$. The salinity of the section in 2018 ranged from $33.77^{\circ} \mathrm{C}(5 \mathrm{~m}$ at station 18 A14) to $35.39^{\circ} \mathrm{C}(150 \mathrm{~m}$ at station $18-\mathrm{A} 17)$, with an average of 34.57 .

The distribution of the VSI in latitude for the three cruises is shown in Fig. 3. Overall, the VSI showed a similar distribution pattern in the three cruises, with the highest value occurring at $7-8^{\circ} \mathrm{N}$ and a decreasing trend with increasing latitude. In the 2016 cruise (Fig. 3a), the minimum value of VSI (2.54) appeared in the station at $20^{\circ} \mathrm{N}$ (station 16-B4), and the maximum value (4.94) appeared in the station at $7^{\circ} \mathrm{N}$ (station 16-A11), with an average of $3.90 \pm 0.76$. In the 2017 cruise (Fig. 3b), a minimum value of VSI (2.85) appeared in the station at $18^{\circ} \mathrm{N}$ (station 17-B4), and the maximum value (5.54) appeared in the station at $7^{\circ} \mathrm{N}$ (station 17-A14), with an average of $4.30 \pm 0.82$. In the 2018 cruise (Fig. 3c), the minimum value of VSI (2.50) occurred in the station at $18^{\circ} \mathrm{N}$ (station 18-B1), and the maximum value (5.48) oc- curred in the station at $8^{\circ} \mathrm{N}$ (station 18-A14), with an average of $4.01 \pm 0.95$. Interestingly, the VSI varied significantly across latitudinal regions; the VSI was high from the Equator to $10^{\circ} \mathrm{N}$, while it was low at $10-20^{\circ} \mathrm{N}$.

\subsection{Interannual variation of phytoplankton communities}

Figure $4 \mathrm{a}, \mathrm{b}$, and $\mathrm{c}$ show the horizontal distribution of surface phytoplankton abundance from 2016 to 2018. The interannual variation in phytoplankton was relatively stable, and the sampling area and sampling time from 2016 to 2018 were generally consistent. Most phytoplankton species varied little from year to year in their distribution. Phytoplankton distribution showed a trend of decreasing abundance from the Equator to the north with a minor abundance peak at about $10^{\circ} \mathrm{N}$. This abundance peak was associated with the predominance of Trichodesmium. However, affected by coastal currents, high-abundance patches dominated by diatoms were also observed in the Luzon Strait area south of Taiwan, which were carried to the surface by upwelling currents and accounted for more than $67.76 \%$ of the abundance at this station. Relatively high abundances were observed at stations in the Kuroshio Current extension region, consisting mainly of cosmopolitan and warm-water species. Phytoplankton abundance was the lowest in the high-latitude region.

\subsection{Vertical distribution of phytoplankton abundance}

Figure 5 shows the vertical distribution of the phytoplankton. The overall trend in the WPO was consistent across the three cruises in 2016 (Fig. 5a), 2017 (Fig. 5b), and 2018 (Fig. 5c), with the phytoplankton distribution showing variations with latitude and differences in vertical distribution at depth. In terms of latitude, high-phytoplankton-value areas were concentrated near the Equator $\left(0-8^{\circ} \mathrm{E}\right)$. Vertical distribution of phytoplankton indicated that the plankton-abundant areas occurred from $0-50 \mathrm{~m}$, and the phytoplankton abundance gradually decreased with the increase in depth. Vertical distribution of phytoplankton abundance differed significantly across different areas. In the areas near the Equator affected by the Halmahera Eddy (HE) and Mindanao Eddy (ME), phytoplankton abundance was mainly concentrated in the upper water column $(0-50 \mathrm{~m})$ and consisted mainly of cyanobacteria. In the northern area affected by the Kuroshio Current, the lower phytoplankton abundance was mostly dominated by the equatorial stations, while the phytoplankton species composition was mostly dominated by diatoms and dinoflagellates.

\subsection{Phytoplankton community structure}

Since there was little interannual difference between species, we clustered all species based on Bray-Curtis similarity distance for stations, and the results showed four distinct regions (Fig. 6). Cluster analysis divided the phytoplankton 


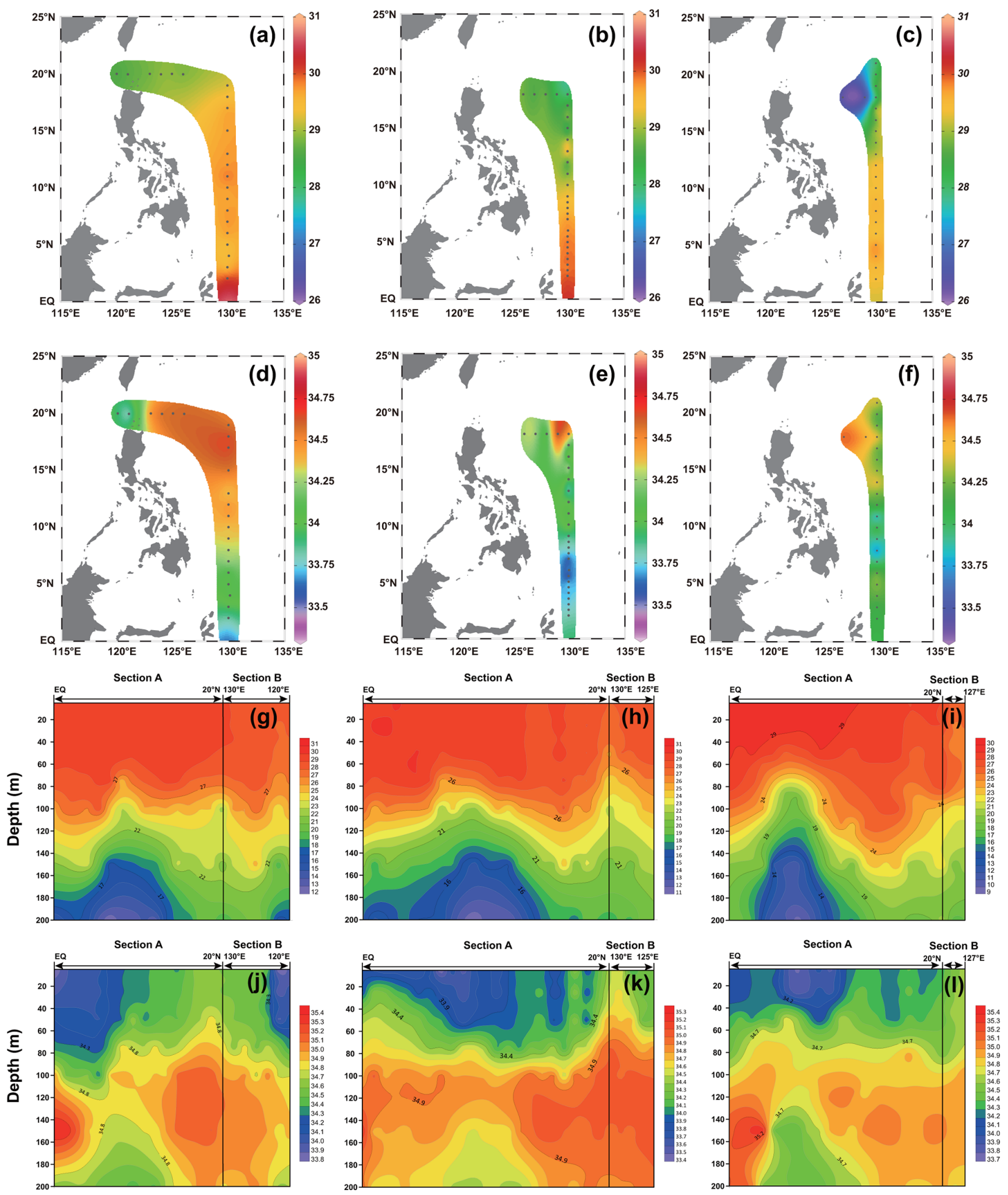

Figure 2. The temperature and salinity distribution in the WPO from three cruises. (a-c) Surface temperature in 2016, 2017, and 2018, respectively; (d-f) surface salinity in 2016, 2017, and 2018, respectively; (g-i) vertical distribution of temperature in 2016, 2017, and 2018, respectively; and (j-l) vertical distribution of salinity in 2016, 2017, and 2018, respectively. 

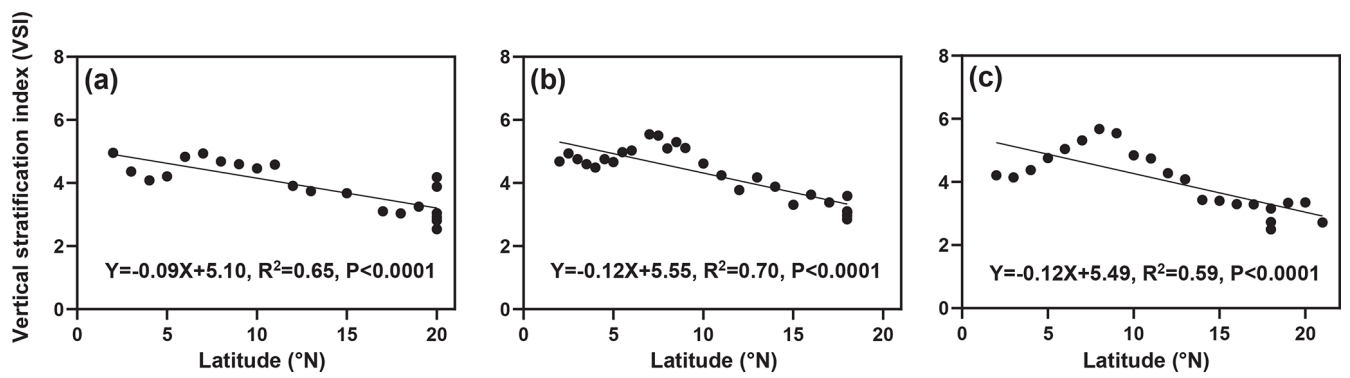

Figure 3. Linear fits of the vertical stratification index with latitude (a) in 2016, (b) 2017, and (c) 2018. The black dots are the VSI of each station.
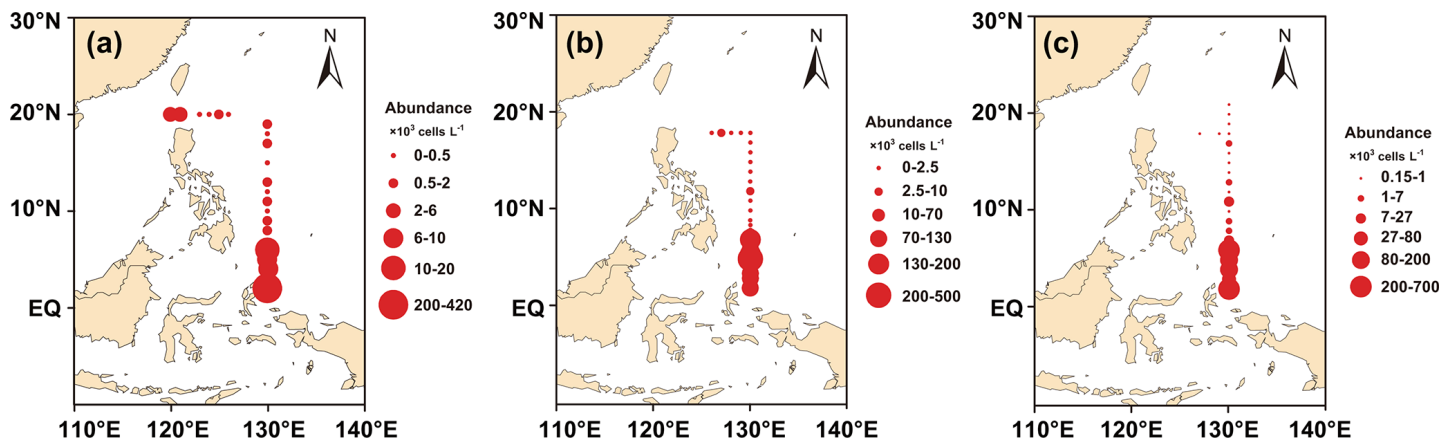

Figure 4. Horizontal distribution of phytoplankton abundance in the WPO: (a) surface layer in 2016, (b) surface layer in 2017, and (c) surface layer in 2018.

communities at the sampling sites over 3 years into four groups. Cyanobacteria $(>90 \%)$ were the dominant species in Groups A and B. The species ratio of diatoms to dinoflagellates in Group A (dias: dinos $=4.8$ ) was higher than that in Group B (dias: dinos $=1.4$ ). Cyanobacteria were the dominant $(66 \%)$ phytoplankton at the stations of Group C, while diatoms $(18 \%)$ and dinoflagellates $(14 \%)$ constituted $32 \%$ of the population in this group. Diatoms $(43 \%)$ and dinoflagellates ( $49 \%$ ) dominated the stations in Group D, accounting for approximately $92 \%$ of the total phytoplankton. The proportion of Chrysophyceae was low in all four groups (Table 1). The dendrogram showed that these populations were grouped into four groups that were essentially identical to those determined by PCoA analysis (Fig. 7).

\subsection{Relationships between phytoplankton and environmental factors}

The relationship between phytoplankton and environmental factors was analyzed using RDA. We obtained a twodimensional distribution map of the species, sample distribution, and environmental factors (Fig. 8). The results showed that different phytoplankton classes were correlated differently with environmental factors. Cyanobacteria showed negative correlations with temperature and salinity and positive correlations with VSI and nutrient concentration, indicating that waters with high VSI are suitable for the growth of cyanobacteria (mostly Trichodesmium). Diatoms and dinoflagellates exhibited positive correlations with temperature and salinity and negative correlations with VSI and nutrient concentration, indicating that diatoms and dinoflagellates prefer waters with low VSI.

There were four distinct phytoplankton communities in the WPO: Group A was distributed in the equatorial region with clear vertical stratification. This community is characterized by high abundance and is dominated by Trichodesmium species such as T. thiebautii, T. hildebrandtii, and T. erythraeum, which are positively correlated with high concentrations of DIN, phosphate, and silicate. Group B was located near $8^{\circ} \mathrm{N}$ and is mainly influenced by the NECC and mesoscale eddies; the phytoplankton community was represented by warm-water species, similar to that of Group A. Group $\mathrm{C}$ was mainly distributed in the $15^{\circ} \mathrm{N}$ region and was strongly influenced by the NEC. Group D was mainly distributed in the $20^{\circ} \mathrm{N}$ region, where it was directly influenced by the Kuroshio Current; here, the phytoplankton community was positively correlated with temperature and salinity.

\subsection{Temperature, salinity, and vertical stratification index}

The temperature, salinity, and VSI of the four groups are shown in Fig. 9. The temperature and salinity $(T-S)$ box diagram depicts the four main water masses in the WPO. 

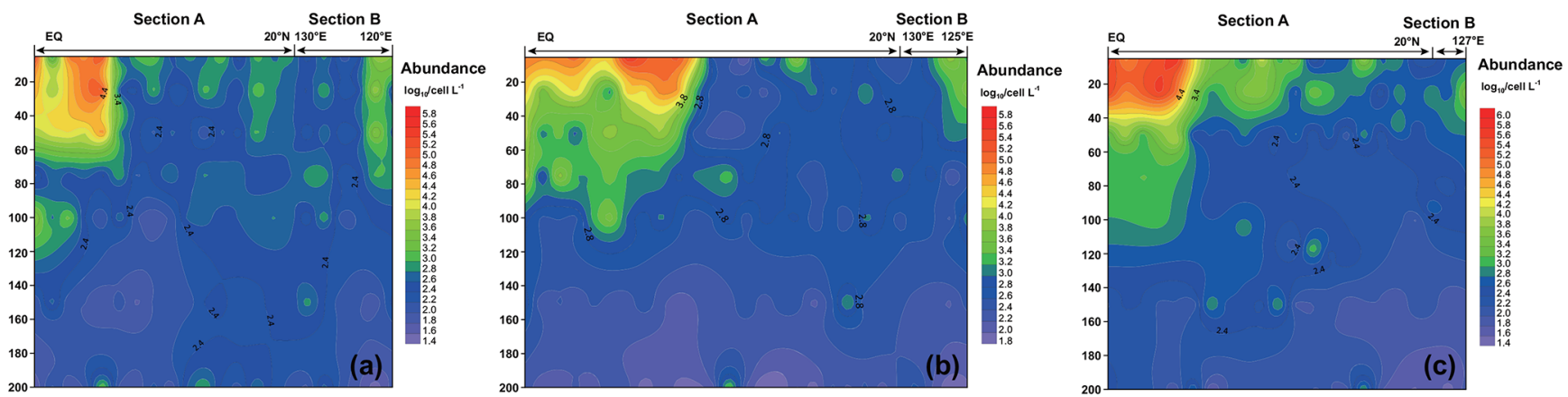

Figure 5. Vertical distribution of phytoplankton abundance ( $\log 10$ cells $\mathrm{L}^{-1}$ ) in the WPO in 2016 (a), 2017 (b), and 2018 (c).

Table 1. The percentages (\%) (average \pm standard deviation) of diatoms, dinoflagellates, cyanobacteria, and Chrysophyceae in the four groups.

\begin{tabular}{lrrrr}
\hline Species & Group A & Group B & Group C & Group D \\
\hline Diatoms & $1.09 \pm 0.79$ & $4.25 \pm 1.57$ & $21.83 \pm 11.45$ & $43.71 \pm 10.12$ \\
Dinoflagellates & $0.44 \pm 0.42$ & $3.41 \pm 3.30$ & $17.26 \pm 12.45$ & $48.38 \pm 11.61$ \\
Cyanobacteria & $98.45 \pm 1.10$ & $92.08 \pm 4.79$ & $59.05 \pm 20.38$ & $6.06 \pm 4.93$ \\
Chrysophyceae & $0.02 \pm 0.01$ & $0.26 \pm 0.10$ & $1.86 \pm 1.99$ & $1.85 \pm 1.66$ \\
\hline
\end{tabular}

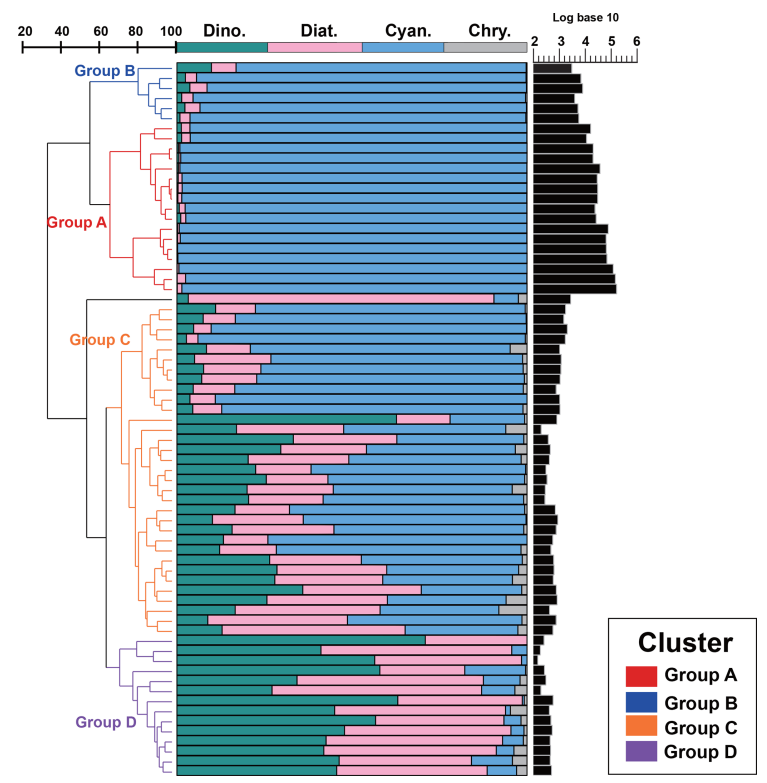

Figure 6. Bray-Curtis similarity-based dendrogram showing averaged phytoplankton community composition and abundance for each station across the three cruises. For each station, community composition is indicated with bar plots and phytoplankton abundance is represented with black bars.

Groups A (average $29.8^{\circ} \mathrm{C}$ ) and B (average $29.6^{\circ} \mathrm{C}$ ) had high temperatures, but the salinities of Groups $\mathrm{A}$ (average $33.9^{\circ} \mathrm{C}$ ) and $\mathrm{B}\left(\right.$ average $33.8^{\circ} \mathrm{C}$ ) were low. The temperature of Groups $\mathrm{C}$ (average $28.9^{\circ} \mathrm{C}$ ) and $\mathrm{D}$ (average $28.9^{\circ} \mathrm{C}$ ) were low, but the salinity of Groups C (average 34.2 ) and D (aver-

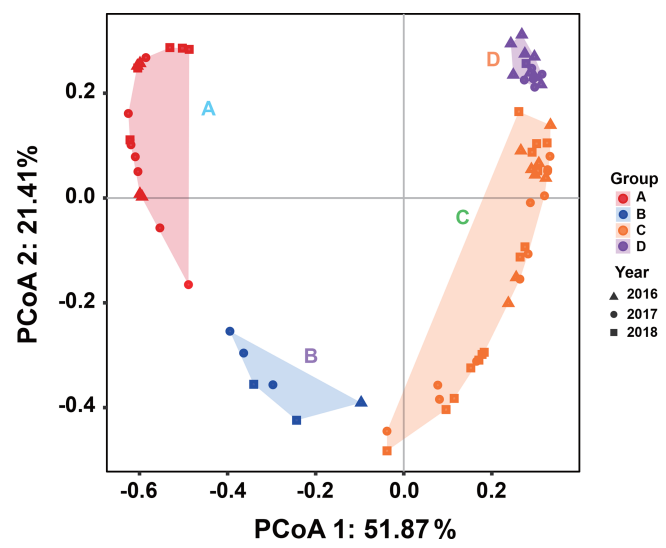

Figure 7. Principal coordinates analysis for groups. Triangles, circles, and squares represent 2016, 2017, and 2018 stations, respectively. $P<0.05$. Different colors represent different groups. Percentages of total variance are explained by coordinates 1 and 2, accounting for $51.87 \%$ and $21.41 \%$, respectively.

age 34.4) were high (Fig. 9a). Figure 9 shows clear variation in $T-S$, and we also calculated the vertical stratification index of the four groups (Fig. 9b). Compared with Groups C (average 3.86) and D (average 3.54), the values of VSI in Groups A (average 4.69) and B (average 4.86) were markedly higher, and Group A had the highest VSI. The stratification of the first two groups was more pronounced (Table 2).

The vertical stratification index was related to temperature (Fig. 9a) and salinity (Fig. 9b). Temperature is positively correlated with the vertical stratification index. The VSI of all groups was negatively correlated with salinity. The changes 

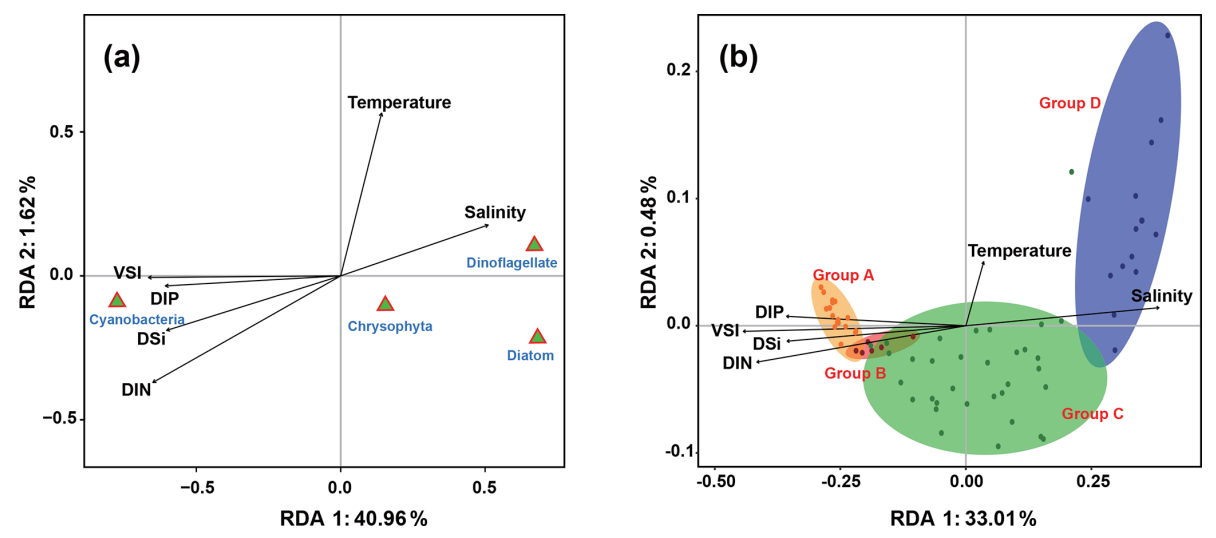

Figure 8. Redundancy analysis of the (a) phytoplankton and environmental parameters. (b) Groups and environmental parameters in the WPO. Colored dots represent sampling sites, triangles represent phytoplankton species, and arrows represent environmental factors.

in temperature and salinity were most pronounced in the vertical direction. In Groups A and B with a high stratification index, the changes in temperature and salinity within the group were small. However, the temperature and salinity changed significantly within Groups C and D, with a small stratification index.

\subsection{Direct vs. indirect effects of environmental parameters on phytoplankton abundance}

The causal relationships between measured phytoplankton abundance and relevant physical and chemical parameters were examined using SEM, focusing on interactions between temperature, salinity, VSI, DIN, and DIP (Fig. 10) as theoretical and experimental data indicated the importance of these variables. The model results showed that temperature, DIP, and DIN had a direct effect on phytoplankton abundance, with temperature having the largest direct effect on phytoplankton abundance (0.38), followed by DIN $(0.28)$ and DIP (0.24). Temperature, salinity, and VSI had indirect effects on phytoplankton abundance, with temperature and salinity having negative indirect effects on phytoplankton abundance $(-0.17$ and -0.30$)$ and VSI having positive indirect effects (0.31) (Fig. 10). From the results of the total effect, only salinity had a negative effect on phytoplankton abundance $(-0.30)$, while both temperature and VSI had positive effects on phytoplankton abundance $(0.20$ and 0.31 ), with VSI having the largest total effect. Although the direct effect of temperature on phytoplankton abundance was significant, it was partially offset by the indirect negative effect, while VSI had no direct effect on phytoplankton abundance, but its larger indirect effect resulted in the largest total effect. Both DIN and DIP had positive effects on phytoplankton abundance, but the effect of DIN was greater. Since the vertical distribution of DIN and DIP exhibited stronger variability, more specific analyses of DIN and DIP will be conducted later.

We analyzed the N:P ratio of the surface layer, the subsurface chlorophyll maximum (SCM) layer, and at $200 \mathrm{~m}$.
The $\mathrm{N}: \mathrm{P}$ ratio in the surface layer $(\mathrm{N}: \mathrm{P}>16: 1)$ indicates phosphorus limitation, which is consistent with the SEM analysis (Fig. 11). The trophic structure of the SCM layer changed, $\mathrm{N}: \mathrm{P}<16: 1$ indicated nitrogen limitation, and the depth continued to increase to the bottom of the euphotic layer and stabilized around $\mathrm{N}: \mathrm{P}=16: 1$, indicating that at the bottom of the euphotic layer, as phytoplankton abundance decreased and interspecific competition decreased, the trophic ratio approached the Redfield ratio and growth may have become increasingly limited by light.

\section{Discussion}

\subsection{Comparison with historical data}

The Kuroshio Current and Western Pacific Warm Pool (WPWP) are key areas of the WPO sea-air interaction and climate modulation (Zhang, 1999). Previous surveys have provided less knowledge of the phytoplankton community structure in this study area (Table 3). Previously, samples were collected by net, and net-collected samples reduced phytoplankton abundance in small volumes, thereby underestimating the phytoplankton abundance in the ocean under investigation. In the present study, phytoplankton samples were collected from water samples, which better reflected the phytoplankton community structure and abundance. Sun et al. (2000) and Liu et al. (2000) further investigated the species composition and abundance distribution of phytoplankton diatoms and dinoflagellates in the Ryukyu Islands and nearby waters. Li et al. (2015) conducted a study on phytoplankton in the tropical and subtropical Pacific oceanic zones with response mechanisms to the limitation of nitrogen and iron. Y. Chen et al. (2018) investigated the phytoplankton community structure and mesoscale eddies in the western boundary current. A total of 199 species in 61 genera belonging to four phytoplankton families were identified, among which the abundance of Trichodesmium species was 

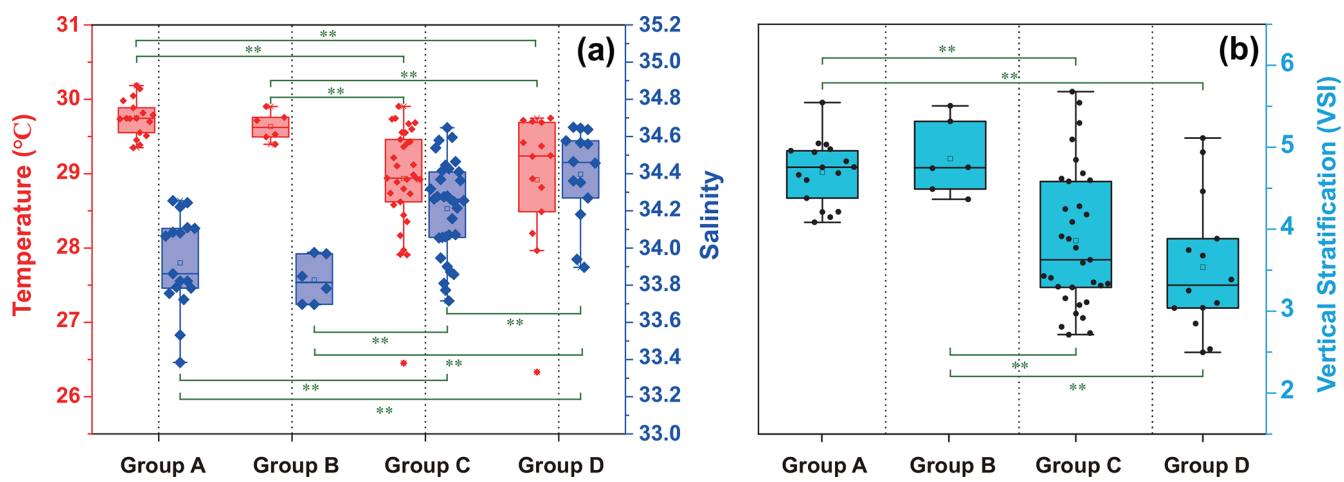

Figure 9. Surface temperature and salinity (a), and vertical stratification index (b) of the four groups.

Table 2. Average ( \pm standard deviation) values for nutrients $\left(\mu \mathrm{mol} \mathrm{L}^{-1}\right)$, temperature $\left({ }^{\circ} \mathrm{C}\right)$, and salinity for each phytoplankton community group identified by the cluster analysis in the WPO.

\begin{tabular}{lrrrr}
\hline & Group A & Group B & Group C & Group D \\
\hline Temperature & $25.30 \pm 1.06$ & $24.45 \pm 1.85$ & $24.92 \pm 1.32$ & $25.41 \pm 1.23$ \\
Salinity & $34.45 \pm 0.14$ & $34.40 \pm 0.07$ & $34.56 \pm 0.16$ & $34.68 \pm 0.20$ \\
DIP & $0.28 \pm 0.07$ & $0.18 \pm 0.13$ & $0.16 \pm 0.13$ & $0.13 \pm 0.10$ \\
DIN & $4.49 \pm 1.76$ & $5.43 \pm 2.71$ & $2.62 \pm 1.89$ & $1.80 \pm 1.08$ \\
DSi & $2.93 \pm 1.05$ & $4.13 \pm 2.15$ & $1.90 \pm 1.47$ & $1.44 \pm 0.95$ \\
VSI & $4.69 \pm 0.39$ & $4.86 \pm 0.45$ & $3.86 \pm 0.84$ & $3.54 \pm 0.82$ \\
\hline
\end{tabular}

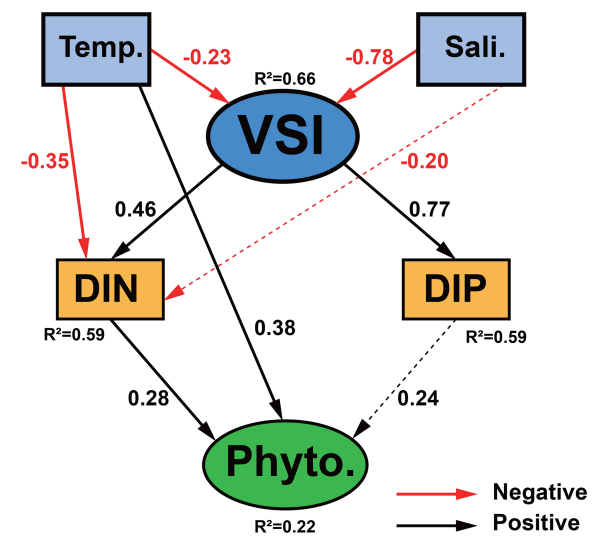

Chi-square $=8.385, \mathrm{p}=0.211, \mathrm{CFI}=0.989, \mathrm{GFI}=0.963$

Figure 10. Structural equation model (SEM) analysis examining the effects of temperature, salinity, VSI, DIN, and DIP on phytoplankton abundance. Solid black and red lines indicate significant positive and negative effects at $p<0.05$, respectively, and dashed black and red lines indicate insignificant positive and negative effects, respectively. $R^{2}$ values associated with response variables indicate the proportion of variation explained by relationships with other variables. Values associated with arrows represent standardized path coefficients. high. Previous studies have mostly focused on vertical hauls and the horizontal distribution of phytoplankton throughout the water column while ignoring the effect of vertical stratification on phytoplankton.

\subsection{Relationship between $\mathrm{N}: \mathrm{P}$ ratio and vertical distribution of phytoplankton}

Research into the factors that control the structure of the phytoplankton community has been carried out for decades, but the hypothesis of nutrient concentration limits and ratios has not been fully explained in terms of affecting the structure of the phytoplankton community (Gao et al., 2019). As diatoms and dinoflagellates show great differences in cell morphology, structure, and nutrition mode, they differ greatly in their nutrient acquisition strategies. Several studies have revealed that dinoflagellates use mixotrophy, engulfing prey and feeding using peduncles and pallia, while phosphorus limitation is a common factor stimulating dinoflagellates to ingest particulate nutrients (Huang et al., 2005; Smayda, 1997; Stoecker, 1999). The variation in phytoplankton community structure is always correlated with fluctuations in physicochemical environmental parameters.

In the four groups we studied, surface seawater $\mathrm{N}: \mathrm{P}>16: 1$ indicated that phosphorus in surface seawater was limited but that Trichodesmium relied on its own nitrogen fixation function and was highly abundant in oligotrophic waters (Fig. 6). The relationship between Tri- 

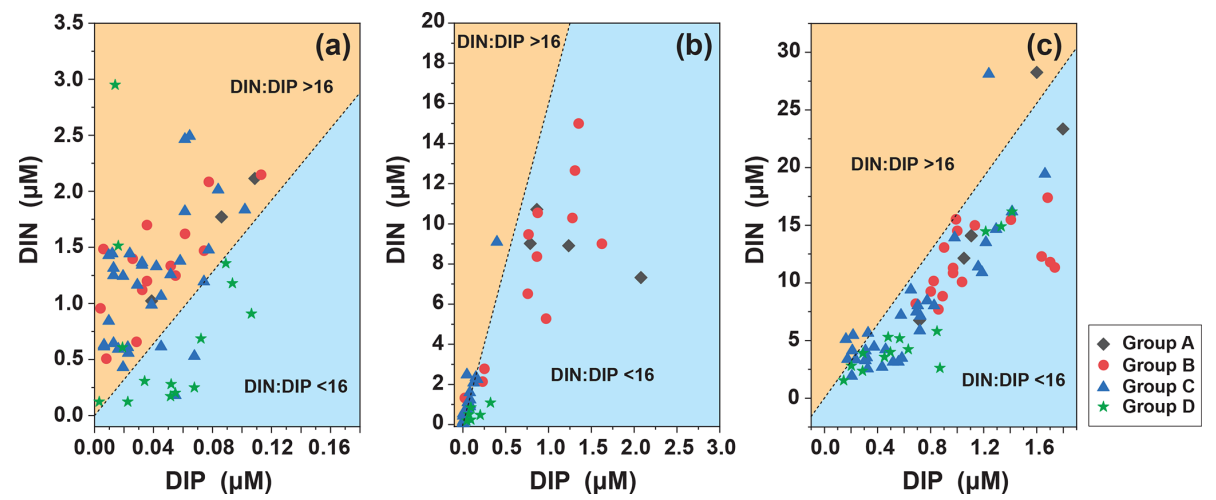

Figure 11. Distribution of phytoplankton community in DIN and DIP (a) at $5 \mathrm{~m}$, (b) the SCM layer, and (b) at $200 \mathrm{~m}$. The dashed line indicates the Redfield ratio of $\mathrm{N}: \mathrm{P}=16: 1$.

Table 3. Historical data of the phytoplankton community in the WPO.

\begin{tabular}{lllrll}
\hline Month & Sampling areas & Layer $(\mathrm{m})$ & Number of species & Sampling types & References \\
\hline Oct 2018 & $2-20^{\circ} \mathrm{N}, 120-130^{\circ} \mathrm{E}$ & $0-200$ & 305 & Water samples & This study \\
Oct 2017 & $2-18^{\circ} \mathrm{N}, 126-130^{\circ} \mathrm{E}$ & $0-200$ & 339 & Water samples & This study \\
Aug 2017 & $10.3-10.9^{\circ} \mathrm{N}, 139.8-140.4^{\circ} \mathrm{E}$ & $0-200$ & 147 & Water samples & Dai et al. (2020) \\
Aug 2017 & $21-42^{\circ} \mathrm{N}, 118-156^{\circ} \mathrm{E}$ & $0-200$ & 235 & Water and net samples & Lin et al. (2020) \\
May 2017 & $21-42^{\circ} \mathrm{N}, 118-156^{\circ} \mathrm{E}$ & $0-200$ & 248 & Water and net samples & Lin et al. (2020) \\
Sep 2016 & $2-21^{\circ} \mathrm{N}, 127-130^{\circ} \mathrm{E}$ & $0-200$ & 269 & Water samples & This study \\
Sep 2016 & $0-20^{\circ} \mathrm{N}, 120-130^{\circ} \mathrm{E}$ & $0-200$ & 243 & Net samples & Z. Chen et al. (2018) \\
Aug 2014 & $0-21.5^{\circ} \mathrm{N}, 121-135.5^{\circ} \mathrm{E}$ & 199 & Net samples & Y. Chen et al. (2018) \\
Jul 1997 & $23^{\circ} 30^{\prime}-29^{\circ} 30^{\prime} \mathrm{N}, 122^{\circ} 30^{\prime}-130^{\circ} 30^{\prime} \mathrm{E}$ & $0-200$ & 227 & Net samples & Sun et al. (2000) \\
Jul 1997 & $23^{\circ} 30^{\prime}-29^{\circ} 30^{\prime} \mathrm{N}, 122^{\circ} 30^{\prime}-130^{\circ} 30^{\prime} \mathrm{E}$ & $0-200$ & 251 & Net samples & Liu et al. (2000) \\
\hline
\end{tabular}

chodesmium and nitrogen fixation has already been demonstrated (Grosskopf et al., 2012; Luo et al., 2012; Zehr, 2011). The virtual absence nitrogen limitation in surface seawater in Group D was consistent with the low abundance of Trichodesmium, which was consistent with studies on the abundance of Trichodesmium in the region (Chen et al., 2019; Sohm et al., 2011). In the WPO, the most oligotrophic ocean in the world (Hansell and Feely, 2000), nutrients have become an important factor that determines the distribution of phytoplankton. Under nutrition-limited conditions, diatoms and dinoflagellates are more affected, especially under phosphorus limitation (Egge, 1998), which corresponds to the high abundance of Group D diatoms and dinoflagellates. In the present study, the vertical pattern of $\mathrm{N}: \mathrm{P}$ ratios indicated differences in nutrient composition along the vertical gradient. The $\mathrm{N}: \mathrm{P}$ ratio of the surface layer $(\mathrm{N}: \mathrm{P}>16: 1)$ indicates phosphorus limitation. The structure of nutrients in the SCM layer changed, and $(\mathrm{N}: \mathrm{P}<16: 1)$ indicates nitrogen limitation. The depth continued to increase to the bottom of the euphotic layer and was stable near $(\mathrm{N}: \mathrm{P}=16: 1)$, indicating that at the bottom of the euphotic layer, where there is decreasing phytoplankton abundance, interspecific competition is reduced as light limitation kicks in, and the nutrient ratio approaches the Redfield ratio. The differences in nutrient ratios thus affect the vertical distribution patterns of phytoplankton abundance. Diatoms have higher phosphorus requirements than other phytoplankton groups, which may be reflected by the lower $\mathrm{N}: \mathrm{P}$ ratio in diatoms than in other groups (Hillebrand et al., 2013). Iron is essential for the synthesis of nitrogen-fixing enzymes in Trichodesmium, and Trichodesmium has a higher demand for iron than other planktonic organisms. The main source of iron in the open ocean is atmospheric deposition. Duce and Tindale (1991) showed that the flux of iron deposition is higher in the WPO, and thus iron is an important environmental limiting factor for the growth of Trichodesmium in addition to temperature. We suggest that some of the sampled phytoplankton may have recently sunk from the upper layers and therefore represents nutrient rationing and $T-S$ in the water layers. Directly sinking phytoplankton cells are major contributors to surface carbon export and an important component of ocean carbon sink (Boyd and Newton, 1999). The phytoplankton cells can regulate their sinking rates in a variety of ways, such as via their physiological state (Eppley et al., 1967), morphology (Pitcher et al., 1989), interaction with light (Bienfang, 1981), and interaction with environmental factors such as temperature and nutrients (Titman and Kilham, 1976). 


\subsection{Vertical stratification determined the vertical distribution of phytoplankton}

The WPO is a oligotrophic area with strong stratification. We found that the interannual variation of phytoplankton was not significant. It remained stably oligotrophic, and the vertical stratification structure determined that of environmental resources such as nutrients, thus forming four contrasting environments, each with its characteristic phytoplankton community structure. Comparative analysis of the phytoplankton community composition of the four groups showed that the phytoplankton was mainly strongly affected by the vertical stratification, which corresponds to previous research (Bouman et al., 2011; Hidalgo et al., 2014; Mojica et al., 2015). Vertical stratification limits the replenishment of nutrients from the deep layer below the thermocline, which affects the $\mathrm{N}: \mathrm{P}$ ratio and restricts vertical migration in addition to physiologically affecting the vertical structure of phytoplankton growth and mortality (Gupta et al., 2020).

In the present study, Trichodesmium was the dominant cyanobacterial species. Marine Trichodesmium is considered the most critical autotrophic nitrogen-fixing cyanobacteria (Dugdale et al., 1961). Trichodesmium can be divided into two forms: clusters and free filaments. Trichodesmium thrives in waters above $20^{\circ} \mathrm{C}$ and has a special cellular air sac structure that allows it to move vertically within the upper $100 \mathrm{~m}$ of the ocean water column (Laroche and Breitbarth, 2005). In the process of water blooms formed by Trichodesmium, a large amount of nitrogen is often fixed in a relatively short period of time. Therefore, the study of the nitrogen fixation rate of Trichodesmium is crucial for estimating the rate of nitrogen fixation in the ocean (Karl et al., 2002). Previous studies have not clarified which factors are the main causes of Trichodesmium growth (possibly temperature, wind, iron, phosphorus, etc.) (Capone et al., 1997; Chang et al., 2000; Sañudo-Wilhelmy et al., 2001; Karl and Tien, 1997). Many researchers have proposed that temperature is the most important factor affecting the growth of Trichodesmium (Capone and Carpente, 1999; Kustka et al., 2002). However, we suggest that there is no single positive correlation between temperature and Trichodesmium growth, which also is consistent with the study of Chang et al. (2000). In the tropical WPO, where the surface temperatures all exceeded $20^{\circ} \mathrm{C}$, the abundance of Trichodesmium in areas with higher temperatures (Groups A and B) was higher than in those with lower temperatures (Groups $\mathrm{C}$ and $\mathrm{D}$ ). Temperature not only directly affected phytoplankton growth but also indirectly affected phytoplankton growth and abundance by regulating VSI to drive the nutrient ratio (N:P) (Fig. 10).

Previous models and field experiments have shown that the species composition of phytoplankton communities is significantly affected by vertical turbulent mixing changes (Huisman et al., 2004). A strong coupling exists among the nutrient supply rate, the photosynthetic performance of phytoplankton (Bouman et al., 2006), and the phytoplankton biomass and primary production, particularly in eutrophic areas (Richardson and Bendtsen, 2019). The vertical stratification index reflects the potential effects of vertical stratification on various physical and chemical processes, such as regulating the utilization of light and nutrients in the ocean, which in turn affects phytoplankton dynamics. The results of the present study showed that from the Equator to the north, the VSI decreases as the latitude increases and that the phytoplankton community structure changes from cyanobacteria to diatoms. Phytoplankton abundance was significantly different in the water layer above the SCM. The water layer below the SCM tended to be stable. The surface phytoplankton abundance was usually greater than that of the SCM layer and was related to the surface layer of Trichodesmium. Our results demonstrate that the highly stratified region was more suitable for the growth of Trichodesmium, while the region with low vertical stratification seems to be more conducive to diatoms and dinoflagellates (Figs. 6 and 8). Due to their low mobility and high potential growth rate, diatoms can reproduce rapidly in mixed water with high nutrient content (Tilman et al., 1986). The weak vertical stratification of the Group C and D regions (Fig. 9b) leads to relative homogeneity of temperature, salinity, density, and nutrients in the upper layer of $200 \mathrm{~m}$ in the vertical direction (Pérez et al., 2006). The vertical distribution of zooplankton has shown that vertical stratification can hinder the migration of small zooplankton populations and indicate different grazing pressures (Mitra and Flynn, 2005; Long et al., 2021). Further research should consider the difference in predation pressure of different zooplankton predators on the composition of the phytoplankton community in different regions. Phytoplankton stratification may cause thin-layer algal blooms and other phenomena, and the influence of phytoplankton stratification can be investigated in further studies.

\section{Conclusions}

This study investigated the phytoplankton community structure of the WPO in the autumn of 2016, 2017, and 2018. The WPO is a oligotrophic ocean with a weak water exchange capacity owing to the thermocline and severe stratification in the upper seawater layer. The phytoplankton community structure mainly consisted of cyanobacteria, diatoms, and dinoflagellates, while the abundance of Chrysophyceae was low. In terms of spatial distribution, phytoplankton abundance was high from the equatorial region to $10^{\circ} \mathrm{N}$ and decreased with increasing latitude. Phytoplankton showed a high variation in the vertical distribution. The potential influences of physicochemical parameters on phytoplankton abundance were analyzed by a structural equation model (SEM) to determine nutrient ratios driven by vertical stratification to regulate phytoplankton community structure in a typical oligotrophic sea area. Regions with strong vertical stratification (Groups A and B) were more favorable for 
cyanobacteria, whereas weak vertical stratification (Groups $\mathrm{C}$ and D) was more conducive to diatoms and dinoflagellates.

Data availability. All data are available upon request by contacting the correspondence author.

Author contributions. ZC performed the analyses and wrote the article. JS, TG, YW, and GZ conceived the research idea, directed the project, and supported the article revision.

Competing interests. The contact author has declared that neither they nor their co-authors have any competing interests.

Disclaimer. Publisher's note: Copernicus Publications remains neutral with regard to jurisdictional claims in published maps and institutional affiliations.

Acknowledgements. We thank the Natural Science Foundation for its support of the northwestern Pacific voyage for sampling and field experiments. Samples were collected onboard R/V Kexue during an open research cruise (voyage nos. NORC2016-09, NORC201709, and NORC2018-09) supported by the NSFC Shiptime Sharing Project. Thank you to all the staff of Kexue for their help. The authors are grateful for the CTD data provided by Dongliang Yuan Physical Oceanography Research Group, Institute of Oceanography, Chinese Academy of Sciences.

Financial support. This research was financially supported by the National Key Research and Development Project of China (grant no. 2019YFC1407805), the National Natural Science Foundation of China (grant nos. 41876134, 41676112, and 41276124), the Tianjin 131 Innovation Team Program (grant no. 20180314), and the Changjiang Scholar Program of Chinese Ministry of Education (grant no. T2014253) provided to Jun Sun.

Review statement. This paper was edited by Yuelu Jiang and reviewed by three anonymous referees.

\section{References}

Bertilsson, S., Berglund, O., Karl, D. M., and Chisholm, S. W.: Elemental composition of marine Prochlorococcus and Synechococcus, Implications for the ecological stoichiometry of the sea, Limnol. Oceanogr., 48, 1721-1731, https://doi.org/10.4319/lo.2003.48.5.1721, 2003.

Bienfang P. K.: SETCOL - a technologically simple and reliable method for measuring phytoplankton sinking rates, Can. J. Fish. Aquat. Sci., 38, 1289-1294, https://doi.org/10.1139/f81$173,1981$.
Bouman, H. A., Ulloa, O., Scanlan, D. J., Zwirglmaier, K., Li, W., Platt, T., Stuart, V., Barlow, R., Leth, O., Clementson, L., Lutz, V., Fukasawa, M., Watanabe, S., and Sathyendranath, S.: Oceanographic basis of the global surface distribution of Prochlorococcus ecotypes, Science, 312, 918-921, https://doi.org/10.1126/science.1122692, 2006.

Bouman, H. A., Ulloa, O., Barlow, R., Li, W. K. W., Platt, T., Zwirglmaier, K., Scanlan, D. J., and Sathyendranath, S.: Water-column stratification governs the community structure of subtropical marine picophytoplankton, Env. Microbiol. Rep., 3, 473-482, https://doi.org/10.1111/j.1758-2229.2011.00241.x, 2011.

Boyd, P. W. and Newton, P. P.: Does planktonic community structure determine downward particulate organic carbon flux in different oceanic provinces?, Deep-Sea Res. Pt. I, 46, 63-91, https://doi.org/10.1016/S0967-0637(98)00066-1, 1999.

Capone, D. and Carpente, E.: Nitrogen fixation by marine cyanobacteria: historical and global perspectives, Bulletin De Linstitut Océanographique, 19, 235-256, 1999.

Capone, D. G., Zehr, J. P., Paerl, H. W., Bergman, B., and Carpenter, E. J.: Trichodesmium, a globally significant marine Cyanobacterium, Science, 276, 1221-1229, https://doi.org/10.1126/science.276.5316.1221, 1997.

Carlson, C. A.: Production and removal processes, in: Biogeochemistry of marine dissolved organic matter, 91-151, https://doi.org/10.1016/B978-012323841-2/50006-3, Academic Press, Bermuda, 2002.

Chang, J., Chiang, K. P., and Gong, G. C.: Seasonal variation and cross-shelf distribution of the nitrogen-fixing cyanobacterium, Trichodesmium, in southern East China Sea, Cont. Shelf Res., 20, 479-492, https://doi.org/10.1016/S0278-4343(99)00082-5, 2000.

Chen, M., Lu, Y., Jiao, N., Tian, J., Kao, S. J., and Zhang, Y.: Biogeographic drivers of diazotrophs in the western Pacific Ocean, Limnol. Oceanogr., 9999, 1-19, https://doi.org/10.1002/lno.11123, 2019.

Chen, Y., Sun, X., and Zhu, M.: Net-phytoplankton communities in the Western Boundary Currents and their environmental correlations, Chin. J. Oceanol. Limn., 36, 305-31, https://doi.org/10.1007/s00343-017-6261-8, 2018.

Chen, Z., Sun, J., and Zhang, G.: Netz-phytoplankton community structure of the tropical Western Pacific Ocean in summer 2016, Mar. Sci., 42, 114-130, https://doi.org/10.11759/hykx20180331002, 2018.

Cronin, M. F., Bond, N. A., Farrar, J. T., Ichikawa, H., Jayne, S. R., Kawai, Y., Konda, M., Qiu, B., Rainville, L., and Tomita, H.: Formation and erosion of the seasonal thermocline in the Kuroshio Extension recirculation gyre, Deep-Sea Res. Pt. II, 85, 62-74, https://doi.org/10.1016/j.dsr2.2012.07.018, 2013.

Dai, M., Wang, L., Guo, X., Zhai, W., Li, Q., He, B., and Kao, S.-J.: Nitrification and inorganic nitrogen distribution in a large perturbed river/estuarine system: the Pearl River Estuary, China, Biogeosciences, 5, 1227-1244, https://doi.org/10.5194/bg-51227-2008, 2008.

Dai, S., Zhao, Y., Li, X., Wang, Z., Zhu, M., Liang, J., Liu, H., Tian, Z., and Sun, X.: The seamount effect on phytoplankton in the tropical western Pacific, Mar. Environ. Res., 162, 105094, https://doi.org/10.1016/j.marenvres.2020.105094, 2020. 
Doney, S. C.: Plankton in a warmer world, Nature, 444, 695-696, https://doi.org/10.1038/444695a, 2006.

Duce, R. A. and Tindale, N. W.: Atmospheric transport of iron and its deposition in the ocean, Limnol. Oceanogr., 36, 1715-1726, 1991.

Dugdale, R. C., Menzel, D. W., and Ryther, J. H.: Nitrogen fixation in the Sargasso Sea, Deep-Sea Res., 7, 297-300, https://doi.org/10.1016/0146-6313(61)90051-X, 1961.

Egge, J. K.: Are diatoms poor competitors at low phosphate concentrations?, J. Marine Syst., 16, 191-198, https://doi.org/10.1016/S0924-7963(97)00113-9, 1998.

Eppley, R. W., Holmes, R. W., and Strickland J. D. H.: Sinking rates of marine phytoplankton measured with a fluorometer, J. Exp. Mar. Biol. Ecol., 1, 191-208, https://doi.org/10.1016/00220981(67)90014-7, 1967.

Falkowski, P. G., Barber, R. T., and Smetacek, V.: Biogeochemical controls and feedbacks on ocean primary production, Science, 281, 200-206, https://doi.org/10.1126/science.281.5374.200, 1998.

Field, C. B., Behrenfeld, M. J., Randerson, J. T., and Falkowski, P.: Primary production of the biosphere: Integrating terrestrial and oceanic components, Science, 281, 237-240, https://doi.org/10.1126/science.281.5374.237, 1998.

Fogg, G. E.: The ecological significance of extracellular products of phytoplankton photosynthesis, Bot. Mar., 26, 3-14, https://doi.org/10.1515/botm.1983.26.1.3, 1983.

Gao, K., Beardall, J., Häder, D. P., Hall-Spencer, J. M., Gao, G., and Hutchins, D. A.: Effects of ocean acidification on marine photosynthetic organisms under the concurrent influences of warming, UV radiation, and deoxygenation, Front. Mar. Sci., 6, 322, https://doi.org/10.3389/fmars.2019.00322, 2019.

Geider, R. J., Maclntyre, H. L., and Kana, T. M.: A dynamic regulatory model of phytoplanktonic acclimation to light, nutrients, and temperature, Limnol. Oceanogr., 43, 679-694, https://doi.org/10.4319/1o.1998.43.4.0679, 1998.

Goldman, J. C., Mccarthy, J. J., and Peavey, D. G.: Growth rate influence on the chemical composition of phytoplankton in oceanic waters, Nature, 279, 210-215, https://doi.org/10.1038/279210a0, 1979.

Grasshoff, K., Kremling, K., and Ehrhardt, M.: Methods of Seawater Analysis, third, completely revised and extended edition, Wiley-VCH, Weinheim, 193-198, 1999.

Grosskopf, T., Mohr, W., Baustian, T., Schunck, H., Gill, D., Kuypers, M., Lavik, G., Schmitz, R. A., Wallace, D., and Laroche, J.: Doubling of marine dinitrogen-fixation rates based on direct measurements, Nature, 488, 361-364, https://doi.org/10.1038/nature11338, 2012.

Guo, S., Feng, Y., Lei, W., Dai, M., Liu, Z., Bai, Y., and Sun, J.: Seasonal variation in the phytoplankton community of a continentalshelf sea: the East China Sea, Mar. Ecol.-Prog. Ser., 516, 103126, https://doi.org/10.3354/meps10952, 2014.

Gupta, A. S., Thomsen, M., Benthuysen J. A., Hobday, A. J., Oliver, E., Alexander, L. V., Burrows, M. T., Donat, M. G., Feng, M., Holbrook, N. J., Perkins-Kirkpatrick, S., Moore, P. J., Rodrigues, R. R., Scannell, H. A., Taschetto, A. S., Ummenhofer, C. C., Wernberg, T., and Smale, D. A.: Drivers and impacts of the most extreme marine heatwaves events, Sci. Rep., 10, 19359, https://doi.org/10.1038/s41598-020-75445-3, 2020.
Hansell, D. A. and Feely, R. A.: Atmospheric Intertropical Convergence impacts surface ocean carbon and nitrogen biogeochemistry in the western tropical Pacific, Geophys. Res. Lett., 27, 1013-1016, https://doi.org/10.1029/1999g1002376, 2000.

Hidalgo, M., Reglero, P., Álvarez-Berastegui, D., Torres, A. P., Álvarez, I., Rodriguez, J. M., Carbonell, A., Zaragoza, N., Tor, A., Goñi, R., Mallol, S., Balbín, R., and Alemany, F.: Hydrographic and biological components of the seascape structure the meroplankton community in a frontal system, Mar. Ecol.-Prog. Ser., 505, 65-80, https://doi.org/10.3354/meps10763, 2014.

Hillebrand, H., Steinert, G., Boersma, M., Malzahn, A., Meunier, C. L., Plum, C., and Ptacnik, R.: Goldman revisited: Faster-growing phytoplankton has lower N:P and lower stoichiometric flexibility, Limnol. Oceanogr., 58, 2076-2088, https://doi.org/10.4319/lo.2013.58.6.2076, 2013.

Huang, B., Ou, L., Hong, H., Luo, H., and Wang, D.: Bioavailability of dissolved organic phosphorus compounds to typical harmful dinoflagellate Prorocentrum donghaiense Lu, Mar. Pollut. Bull., 51, 838-844, https://doi.org/10.1016/j.marpolbul.2005.02.035, 2005.

Huisman, J., Sharples, J., Stroom, J. M., Visser, P. M., Kardinaal, W. E. A., Verspagen, J. M. H., and Sommeijer, B.: Changes in turbulent mixing shift competition for light between phytoplankton species, Ecology, 85, 2960-2970, https://doi.org/10.1890/030763, 2004.

Jin, D. and Chen, J.: Chinese Marine Planktonic Diatoms, Shanghai Scientific \& Technical Press, 1-230, 1965.

Karl, D., Michaels, A., Bergman, B., Capone, D., Carpenter, E., Letelier, R., Lipschultz, F., Paerl, H., Sigman, D., and Stal, L.: Dinitrogen fixation in the world's oceans, Biogeochemistry, 57/58, 47-98, https://doi.org/10.1007/978-94-017-34059_2, 2002.

Karl, D. M. and Tien, G.: Temporal variability in dissolved phosphorus concentrations in the subtropical North Pacific Ocean, Mar. Chem., 56, 77-96, https://doi.org/10.1016/S03044203(96)00081-3, 1997.

Karl, D. M., Hebel, D. V., Björkman, K., and Letelier, R. M.: The role of dissolved organic matter release in the productivity of the oligotrophic North Pacific Ocean, Limnol. Oceanogr., 43, 1270 1286, https://doi.org/10.4319/lo.1998.43.6.1270, 1998.

Karl, D. M., Björkman, K. M., Dore, J. E., Fujieki, L., Hebel, D. V., Houlihan, T., Letelier, R. M., and Tupas, L. M.: Ecological nitrogen-to-phosphorus stoichiometry at station ALOHA. DeepSea Res. Pt. II, 48, 1529-1566, https://doi.org/10.1016/S09670645(00)00152-1, 2001.

Kustka, A., Carpenter, E. J., and Sañudo-Wilhelmy, S. A.: Iron and marine nitrogen fixation: progress and future directions, Res. Microbiol., 153, 255-262, https://doi.org/10.1016/S09232508(02)01325-6, 2002.

Laroche, J. and Breitbarth, E.: Importance of the diazotrophs as a source of new nitrogen in the ocean, J. Sea Res., 53, 67-91, https://doi.org/10.1016/j.seares.2004.05.005, 2005.

Li, Q., Legendre, L., and Jiao, N. Z.: Phytoplankton responses to nitrogen and iron limitation in the tropical and subtropical Pacific Ocean, J. Plankton Res., 37, 306-319, https://doi.org/10.1093/plankt/fbv008, 2015.

Liu, D. Y., Sun, J., and Qian, S. B.: Planktonic dinoflagellate in Ryukyu-gunto and its adjacent waters-species composition and 
their abundance distribution in summer 1997, Collected Works of Chinese Oceanography, Qingdao, 2000.

Lin, G. M., Chen, Y. H., Huang, J., Wang, Y. G., Ye, Y. Y., and Yang, Q. L.: Regional disparities of phytoplankton in relation to different water masses in the Northwest Pacific Ocean during the spring and summer of 2017, Acta Oceanol. Sin., 39, 107-118, https://doi.org/10.1007/s13131-019-1511-6, 2020.

Long, Y., Noman, A., Chen, D. W., Wang, S. H., Yu, H., Chen, H. T., Wang, M., and Sun, J.: Western pacific zooplankton community along latitudinal and equatorial transects in autumn 2017 (northern hemisphere), Diversity, 13, 58, https://doi.org/10.3390/d13020058, 2021.

Luo, Y.-W., Doney, S. C., Anderson, L. A., Benavides, M., BermanFrank, I., Bode, A., Bonnet, S., Boström, K. H., Böttjer, D., Capone, D. G., Carpenter, E. J., Chen, Y. L., Church, M. J., Dore, J. E., Falcón, L. I., Fernández, A., Foster, R. A., Furuya, K., Gómez, F., Gundersen, K., Hynes, A. M., Karl, D. M., Kitajima, S., Langlois, R. J., LaRoche, J., Letelier, R. M., Marañón, E., McGillicuddy Jr., D. J., Moisander, P. H., Moore, C. M., Mouriño-Carballido, B., Mulholland, M. R., Needoba, J. A., Orcutt, K. M., Poulton, A. J., Rahav, E., Raimbault, P., Rees, A. P., Riemann, L., Shiozaki, T., Subramaniam, A., Tyrrell, T., Turk-Kubo, K. A., Varela, M., Villareal, T. A., Webb, E. A., White, A. E., Wu, J., and Zehr, J. P.: Database of diazotrophs in global ocean: abundance, biomass and nitrogen fixation rates, Earth Syst. Sci. Data, 4, 47-73, https://doi.org/10.5194/essd-447-2012, 2012.

Mena, C., Reglero, P., Hidalgo, M., Sintes, E., Santiago, R., Martín, M., Moyà, G., and Balbín, R.: Phytoplankton community structure is driven by stratification in the oligotrophic mediterranean sea, Front. Microbiol., 10, 1698, https://doi.org/10.3389/fmicb.2019.01698, 2019.

Mitra, A. and Flynn, K. J.: Predator-prey interactions: is 'ecological stoichiometry' sufficient when good food goes bad?, J. Plankton Res., 27, 393-399, https://doi.org/10.1093/plankt/fbi022, 2005.

Mojica, K. D. A., van de Poll, W. H., Kehoe, M., Huisman, J., Timmermans, K. R., Buma, A. G. J., van der Woerd, H. J., HahnWoernle, L., Dijkstra, H. A., and Brussaard, C. P. D.: Phytoplankton community structure in relation to vertical stratification along a north-south gradient in the Northeast Atlantic Ocean, Limnol. Oceanogr., 60, 1498-1521, https://doi.org/10.1002/lno.10113, 2015.

Oksanen, J. F., Blanchet, F. G., Friendly, M., Kindt, R., Legendre, P., McGlinn, D., Minchin, P. R., O’Hara, R. B., Simpson, G. L., Solymos, P., Stevens, M. H., Szoecs, E., and Wagner, H.: vegan: Community Ecology Package, 2020.

Pai, S. C., Tsau, Y. J., and Yang, T. I.: PH and buffering capacity problems involved in the determination of ammonia in saline water using the indophenol blue spectrophotometric method, Anal. Chim. Acta, 434, 209-216, https://doi.org/10.1016/S00032670(01)00851-0, 2001.

Pérez, V., Fernández, E., Marañón, E., Morán, X. A. G., and Zubkov, M. V.: Vertical distribution of phytoplankton biomass, production and growth in the Atlantic subtropical gyres, Deep-Sea Res. Pt. I, 53, 1616-1634, https://doi.org/10.1016/j.dsr.2006.07.008, 2006.

Pitcher G. C., Walker D. R., and Mitchell-Innes B. A.: Phytoplankton sinking rate dynamics in the southern Ben- gurla upwelling system, Mar. Ecol.-Prog. Ser., 55, 261-269, https://doi.org/10.3354/meps055261, 1989.

Qiu, B., Chen, S. M., and Hacker, P.: Synoptic-scale airsea flux forcing in the western North Pacific: Observations and their impact on SST and the mixed layer, J. Phys. Oceanogr., 34, 2148-2159, https://doi.org/10.1175/15200485(2004)034<2148:SAFFIT>2.0.CO;2, 2004.

Redfield, A. C., Ketchum, B. H., and Richards, F. A.: The influence of organisms on the composition of sea-water, Sea, 26-77, https://doi.org/10.1061/40640(305)14, 1963.

Richardson, K. and Bendtsen, J.: Vertical distribution of phytoplankton and primary production in relation to nutricline depth in the open ocean, Mar. Ecol.-Prog. Ser., 620, 33-46, https://doi.org/10.3354/meps12960, 2019.

Sañudo-Wilhelmy, S. A., Kustka, A. B., Gobler, C. J., Hutchins, D. A., Yang, M., Lwiza, K., Burns, J., Capone, D. G., Raven, J. A., and Carpenter, E. J.: Phosphorus limitation of nitrogen fixation by Trichodesmium in the central Atlantic Ocean, Nature, 411, 66-69, https://doi.org/10.1038/35075041, 2001.

Schindler, D. W.: Ecological stoichiometry: The biology of elements from molecules to the biosphere, Nature, 423, 225-226, https://doi.org/10.1038/423225b, 2003.

Smayda, T. J.: Harmful algal blooms: their ecophysiology and general relevance to phytoplankton blooms in the sea, Limnol. Oceanogr., 42, 1137-1153, https://doi.org/10.4319/lo.1997.42.5_part_2.1137, 1997.

Sohm, J. A., Webb, E. A., and Capone, D. G.: Emerging patterns of marine nitrogen fixation, Nat. Rev. Microbiol., 9, 499-508, https://doi.org/10.1038/nrmicro2594, 2011.

Stoecker, D. K.: Mixotrophy among dinoflagellates, J. Eukaryot Microbiol., 46, 397-401, https://doi.org/10.1111/j.15507408.1999.tb04619.x, 1999.

Sun, J. and Liu, D. Y.: The Preliminary Notion on Nomenclature of Common Phytoplankton in China Sea Waters, Oceanologia Et Limnologia Sinica, 33, 271-286, https://doi.org/10.1088/10091963/11/5/313, 2002.

Sun, J., Liu, D. Y., and Qian, S. B.: Planktonic diatoms in Ryukyugunto and its adjacent waters-species composition and abundance distribution in summer 1997, Collected Works of Chinese Oceanography, Qingdao, 2000.

Sun, J., Liu, D. Y., and Qian, S. B.: A Quantative Research and Analysis Method for Marine Phytoplankton: An Introduction to Utermöhl Method and Its Modification, Journal of oceanography of Huanghai \& Bohai Seas, 20, 105-112, 2002.

Titman D. and Kilham P.: Sinking in freshwater phytoplankton: some ecological implications of cell nutrient status and physical mixing processes, Limnol. Oceanogr., 21, 409-417, https://doi.org/10.4319/lo.1976.21.3.0409, 1976.

Tilman, D., Kiesling, R., Sterner, R., Kilham, S. S., and Johnson, F. A.: Green, bluegreen and diatom algae: taxonomic differences in competitive ability for phosphorus, silicon and nitrogen, Arch. Hydrobiol., 106, 473-485, https://doi.org/10.1029/WR022i007p01162, 1986.

Yamaguchi, R., Suga, T., Richards, K. J., and Qiu, B.: Diagnosing the development of seasonal stratification using the potential energy anomaly in the North Pacific, Clim. Dynam., 53, 46674681, https://doi.org/10.1007/s00382-019-04816-y , 2019.

Yamaji, I.: Illustrations of the Marine Plankton of Japan, Hoikusha Press, Tokyo, 1-158, 1991. 
Zehr, J. P.: Nitrogen fixation by marine cyanobacteria, Trend. Microbiol., 19, 162-173, https://doi.org/10.1016/j.tim.2010.12.004, 2011.

Zhang, Q.: Relationship between the precipitation in the rainy season in north China and the tropical western pacific warm pool and Kuroshio, Plateau Meteorology, 18, 575-583, 1999.
Zhu, J., Zheng, Q. A., Hu, J. Y., Lin, H. Y., Chen, D. W., Chen, Z. Z., Sun, Z. Y., Li, L. Y., and Kong, H.: Classification and 3-D distribution of upper layer water masses in the northern South China Sea, Acta Oceanol. Sin., 38, 126-135, https://doi.org/10.1007/s13131-019-1418-2, 2019. 